\title{
The pathophysiology of transfusional iron overload
}

John B Porter M.D. and Maciej Garbowski M.D.

Department of Haematology, University College London, UK

72 Huntley Street, London WC1E 6BT, UK, phone +44 2076796224

j.porter@ucl.ac.uk

Key words: iron overload, pathophysiology, mechanism, thalassemia, sickle cell disease, blood transfusion, ntbi, extra-hepatic iron distribution,

\section{ABSTRACT (247)}

The pathophysiological consequences of transfusional iron overload (TIO) as well as the benefits of iron chelation are best described in Thalassemia Major (TM), although TIO is increasingly seen in other clinical settings. These consequences broadly reflect the levels and distribution of excess storage iron in the heart, endocrine tissues and liver. MRI-visible storage iron does not directly damage cells, but its intracellular turnover contributes to labile iron pools that generate harmful free radicals. TIO also increases the risk of infection, due to increased availability of labile iron to microorganisms. Although storage iron accumulates firstly and predominantly in the liver, heart failure from myocardial iron loading typically precedes the hepatic complications of cirrhosis and hepatocellular carcinoma by at least two decades. With improved chelation, decreased cardiomyopathy and increasing survival, hepatic complications are more commonly encountered. Storage iron distribution reflects the pattern of transferrin-independent iron uptake (NTBI), which in animal models has been linked to L-type calcium channels. The propensity of iron overload to distribute extra-hepatically differs between underlying clinical conditions. Thus Sickle Cell Disease (SCD) patients have a lower risk of myocardial and endocrine iron deposition than TM and also have disproportionately low NTBI levels. Conversely, DiamondBlackfan Anemia (DBA) patients are prone to extra-hepatic iron deposition, and have high levels of NTBI, consistent with low transferrin iron utilization. We suggest that extra-hepatic iron distribution, and hence toxicity, is influenced by balance between generation of NTBI from red cell catabolism and the utilization of transferrin iron by the erythron. 


\section{IRON HOMEOSTATIC MECHANISMS (5004 WORDS)}

Iron homeostatic mechanisms are key to the pathophysiology of TIO. In humans, these mechanisms are best adapted to increasing iron acquisition in conditions of iron deficiency or anemia, or to limiting iron distribution from the macrophage system during inflammation. They are not well adapted, however, to controlling the distribution of TIO or to eliminating excess iron. This is in marked contrast to rodents, where most studies on iron overload and iron metabolism have been performed and where iron overload is eliminated efficiently by the biliary route. Iron homeostasis is adapted to supplying only that which is essential for the functioning of proteins involved in oxygen transport, oxidative energy production, mitochondrial respiration and DNA synthesis, while minimizing the potential for iron toxicity from its redox cycling. These homeostatic mechanisms work at two levels: firstly at the level of the whole body through interactions of plasma hepcidin with membrane ferroportin and secondly at a cellular level through interaction of IRE-binding proteins (IRPs) with iron responsive elements (IREs) present on mRNAs of key iron metabolism-related proteins.

\section{Body iron homeostasis}

A healthy human contains $40-50 \mathrm{mg} / \mathrm{kg}$ of iron, mainly as hemoglobin $(30 \mathrm{mg} / \mathrm{kg})$. About $4 \mathrm{mg} / \mathrm{kg}$ is present in muscle myoglobin, with $2 \mathrm{mg} / \mathrm{kg}$ in cells as iron-containing enzymes. Storage iron, present as ferritin and its compact, partially degraded form hemosiderin, ranges from 0 to $2000 \mathrm{mg}$. $^{1}$ This is mainly present in liver, spleen and bone marrow (BM) macrophages, formerly referred to as the reticulo-endothelial system (RES) and in hepatocytes $^{2}$. Liver iron concentration (LIC) rarely exceeds $1.8 \mathrm{mg} / \mathrm{g}$ dry weight $(\mathrm{dw})$ in healthy individuals in the absence of liver disease, hemochromatosis genes, inappropriate dietary supplementation or blood transfusion.

A healthy individual absorbs only about $10 \%$ of dietary iron or about 1$2 \mathrm{mg} /$ day, usually balanced by iron loss from skin, gut, menstruation or pregnancy. Anemia, hypoxia, ineffective erythropoiesis (IE), and the presence of variant HFE genes increase iron absorption, the common factor being low, or inappropriately low, plasma hepcidin levels ${ }^{3}$. The latter permit higher enterocyte ferroportin expression, allowing Fe(II) flux and hence increasing dietary iron absorption. Iron absorption is also increased through hypoxiainducible factor-1-mediated signaling, by duodenal up-regulation of DcytB and DMT1 expression. ${ }^{4}$ Thus, in principle, any anemia will tend to increase the efficiency of iron absorption. The majority of body iron turnover however, is not directed through iron absorption, but through the plasma transferrin, which, while binding only $1-2 \mathrm{mg}$ of iron at any moment, in a healthy adult delivers about $20-30 \mathrm{mg} /$ day via transferrin receptors on the erythron for hemoglobin synthesis.

Hepcidin regulation is important both to iron absorption from diet and to iron egress from erythrophagocytic macrophages. Hepcidin controls iron egress from both macrophages and enterocytes by binding to and degrading 
ferroportin, through which $\mathrm{Fe}(\mathrm{II})$ exits these cells ${ }^{5,6}$. Hepatic hepcidin synthesis is controlled by at least 3 distinct regulatory mechanisms responsive to levels of iron, erythropoiesis or inflammation.

- Extracellular iron sensing involves the binding of diferric transferrin to transferrin-receptor-1 (TfR1), initiating the translocation of HFE from TfR1 to TfR2 and its subsequent signaling via ERK1/ERK2 and p38 MAP kinase to induce hepcidin expression. Storage iron sensing is effected by BMP6 signaling via BMP receptor (and SMADs pathway) whose sensitivity is markedly increased by its interaction with hemojuvelin, HFE and TfR2 in holotransferrin dependent manner, thus enhancing hepcidin transcription ${ }^{7,8}$.

- Erythropoiesis sensing involves BM-derived factors that suppress hepcidin synthesis; conditions with high levels of IE will have high levels of these factors, the nature of which has been debated. These include $\mathrm{GDF} 15^{9}$, twisted gastrulation factor $-1^{10}$, and most recently erythoferrone $^{11}$ which has been identified as a key factor in mice, although its relevance in humans has yet to be demonstrated. Another separate erythropoiesis sensing mechanism likely involves desaturation of transferrin by the erythron as disruption of transferrin iron uptake into erythron in $h b d$ mouse increases hepcidin despite ongoing anemia, ${ }^{8,12}$ presumably overriding the erythropoietic depressors of hepcidin (or demonstrating that depressors have an effect only with concomitant transferrin desaturation).

- Inflammation sensing mediated through IL-6/STATs pathway and other cytokines up-regulates hepcidin synthesis, ${ }^{13}$ being the key mechanism in hypoferremia of acute inflammation through the action of ferroportin degradation in macrophages ${ }^{5}$.

Erythropoietic drive overrides both iron sensing ${ }^{14-16}$ and inflammation sensing mechanisms ${ }^{17}$, but the extent to which these potentially opposing regulators of hepcidin synthesis play out in the context of iron metabolism in TIO are difficult to predict from murine studies alone and require careful clinical observations. These are discussed below under the clinical condition in question

\section{Cellular iron homeostasis}

Intracellular iron homeostasis is controlled not only by the synthesis of ferritin but also by the regulation of iron uptake through regulation of membrane transferrin receptors (Tfr). Both of these are regulated by IREs, stem-loop structures present in untranslated regions (UTR) of mRNA e.g. in the 5'UTR of H-ferritin or the 3'UTR of TfR mRNA, respectively. These are both sensitive to the magnitude of labile intracellular iron pools (LIP) through interaction with cellular IRPs; the conformation of IRPs and their binding to IREs are sensitive to LIP concentrations. ${ }^{18}$ IRE binding of both IRP1 and IRP2 increases in irondeficient conditions, but both are rapidly degraded by iron and heme. IRP2 has predominant control overall, ${ }^{19}$ while IRP1 can switch from aconitase activity form in iron repletion (dependent on iron-sulphur cluster assembly, $4 \mathrm{Fe}-4 \mathrm{~S}$ ) to IRE-binding form in iron deficiency (losing iron: 3Fe-4S). ${ }^{20}$ Therefore both their cellular level and the position of IRE on mRNA regulate in concert the onset and degree of translation events (5' UTR governing 
access to matrices, 3'UTR governing stability of matrices by regulating the binding of nucleases). High levels of LIP thus increase ferritin synthesis while decreasing the membrane expression of TfR1. However, in the erythron such feedback is absent; instead transcriptional control permits high TfR despite high cellular iron or heme, consistent with hemoglobin synthesis requirements. Most ferroportin transcripts also contain IRE at 5'UTR, and therefore the amount of mRNA is increased in iron overload. However, the effective regulation of ferroportin happens post-translationally through hepcidin-dependent down-regulation ${ }^{6}$ or lack of Fe(II) acceptor. ${ }^{21}$

The availability of iron for the synthesis of iron containing molecules at a cellular level is directed through a transient low molecular weight iron pool, LIP, which in turn determines the levels and action of IRPs. Although LIP iron has been proposed to be coordinated mainly by glutathione from a thermodynamic perspective ${ }^{22}$, its exact nature still remains unclear, but it can potentially redox cycle between $\mathrm{Fe}(\mathrm{II})$ and $\mathrm{Fe}(\mathrm{III})$ with consequent generation of harmful free radicals. In order to minimize these risks, elegant homeostatic mechanisms carefully coordinate the distribution of body iron so as to provide iron pools for efficient synthesis of these proteins, while minimizing ironmediated free radical generation.

\section{IMPACT OF BLOOD TRANSFUSION ON IRON BALANCE}

The rates and nature of blood transfusion regimens affect iron accumulation and its distribution in the body. This is key to the pathophysiology of iron overload and varies with the underlying clinical condition.

\section{Thalassemia Major}

In thalassemia major (TM), blood transfusion typically begins in the first year of life. Current transfusion recommendations in TM aim to keep the pretransfusion hemoglobin level at approximately $9.5 \mathrm{~g} / \mathrm{dl}$ and to maintain an average hemoglobin of $12 \mathrm{~g} / \mathrm{dll}^{23}$ which usually amounts to an iron load rate (ILR) of $0.3-0.5 \mathrm{mg} / \mathrm{kg} / \mathrm{d} .{ }^{23}$ This regimen has been arrived at so as to balance the beneficial effects of suppression of IE and dietary iron absorption with the iron accumulated from transfusion. The transfusional suppression of the endogenous BM activity can be assessed by monitoring circulating transferrin receptors, which show more suppression when the pre-transfusion hemoglobin level exceeds $10 \mathrm{~g} / \mathrm{dL}^{24}$ Maintenance of a mean pre-transfusion hemoglobin level of $9.4 \mathrm{~g} / \mathrm{dl}$ versus $11.3 \mathrm{~g} / \mathrm{dl}$ decreased net blood consumption and was associated with improved control of iron overload in Italian patients. ${ }^{25}$ This optimal balance may not be universal and may depend on the severity of thalassemia genotype. In the pre-chelation era, LICs of $40 \mathrm{mg} / \mathrm{g} \mathrm{dw}$ were typically seen by 10 years of age. ${ }^{26}$ Failure to control these levels risks extra-hepatic spread of iron (see below).

\section{Sickle cell disease}

The age of commencing blood transfusion, transfusional ILR, and the nature of the transfusion regimen itself, all affect the rate and extent of iron overload 
in SCD and often differ considerably from TM. Net iron accumulation from transfusion in SCD is slower than TM, firstly because of differences in transfusion practice between these conditions and secondly because SCD patients tend to be in negative iron balance in the absence of transfusion. In SCD there is considerable intravascular hemolysis leading to iron loss via urine $^{27-29}$ (as in PNH) and possibly bile ${ }^{30}$. Urinary iron loss in SCD may reach as much as $15 \mathrm{mg} / \mathrm{d}^{28}$ (approx. $0.2 \mathrm{mg} / \mathrm{kg} / \mathrm{d}$ i.e. comparable to average SCD transfusional ILR). Furthermore the marrow is less expanded in SCD than in TM or NTDT, leading to less hepcidin suppression and less tendency for increased iron absorption (Porter 2014, in preparation). Under conditions of hypertransfusion, where synthesis of $\mathrm{HbS}$ is suppressed, or under vigorous chronic automated exchange procedures, were the $\% \mathrm{HbS}$ is maintained at low levels, intravascular hemolysis will also be suppressed and thus the tendency to lose iron through this mechanism will be diminished.

Historically, blood transfusions were typically sporadic and given by simple transfusion or by some form of partial exchange procedure in response to acute episodes, which over a lifetime would lead to significant iron overload. Transfusion has been increasingly given to prevent primary and secondary stroke. ${ }^{31}$ This approach, together with a wider use of transfusion to prevent or treat other complications, such as chest syndrome, or in preparation for major surgery, puts an increasing proportion of patients at risk of TIO. In a large multicenter international study, where most patients received simple $(60 \%)$ or exchange transfusions (20\%), the mean ILR was $0.22 \mathrm{mg} / \mathrm{kg} / \mathrm{day}^{32}$, notably lower than in TM. Manual exchange procedures, where about $1 / 3$ of the blood volume is exchanged, lead to ILR of about $40 \%$ of simple transfusions, as estimated from ferritin increments. ${ }^{33}$ With automated erythrocytapheresis, ILR was only $0.053 \mathrm{mg} / \mathrm{kg} /$ day with a target pre-transfusion $\mathrm{HbS}<50 \%$; ${ }^{34}$ this compared with $0.39 \mathrm{mg} / \mathrm{kg} /$ day for simple transfusion with a target $\mathrm{HbS}<30 \%$ and $0.29 \mathrm{mg} / \mathrm{kg} /$ day with a target $\mathrm{HbS}<50 \%$.

\section{Other conditions}

In other forms of TIO, the rates of ILR again vary considerably; for example a mean of $0.4 \mathrm{mg} / \mathrm{kg} /$ day was found in transfusion-dependent DBA patients with $0.28 \mathrm{mg} / \mathrm{kg} / \mathrm{day}$ in MDS patients in the same study ${ }^{35}$. Patients who receive repeated myelo-ablative chemotherapy cycles for leukemias or lymphomas can accumulate over 100 units of transfused blood or $20 \mathrm{~g}$ of excess body iron that will eventually require removal if long-term iron toxicity is to be avoided.

\section{MECHANISMS OF IRON TOXICITY IN TRANSFUSIONAL OVERLOAD}

The pathophysiological consequences of TIO are summarized in Figure 1. These are broadly observed in tissues in which storage iron accumulates at the highest concentrations. Ferritin within cells is degraded in lysosomes or proteasomes, the iron is released into LIP and this iron is reincorporated into new ferritin synthesis or made available for synthesis of essential iron containing proteins. ${ }^{20}$ Once the LIP reaches a critical concentration, ${ }^{36}$ the iron 
can redox cycle between ferric $\mathrm{Fe}$ (III) and ferrous $\mathrm{Fe}(\mathrm{II})$ forms through the donation or acceptance of an electron and enhance the generation of reactive oxygen species (ROS), with a cascade of consequences (Figure 1). Both the concentration of LIP, as well as the capacity of cells to accommodate increased levels of iron are likely to vary between cell type and the exact nature and redox state of LIP remain unresolved. For example in the human K562 cell line LIP concentrations of $0.24-0.4 \mu \mathrm{M}$ have been estimated using the fluorochrome calcein as a probe ${ }^{37}$. However using EPR spectroscopy which detects $\mathrm{Fe}(\mathrm{III})$ and requires no manipulation of cells, an intracellular EPR-detectable high-spin ferric iron signal was found at approximately $3.2 \mu \mathrm{M}^{38,39}$. More recently, increased levels of LIP have been linked to increased ROS production and potentially oncogenic effects. ${ }^{40}$ Ferritin acts as a sink for LIP by decreasing its magnitude and its potential toxicity. For example, murine erythroleukemia cells overexpressing $\mathrm{H}$-ferritin displayed lower levels of LIP and ROS ${ }^{41}$.

Not all ROS are necessarily toxic to cells however. Large quantities of superoxide are produced naturally by respiration (about $30 \mathrm{~g} / \mathrm{day}$ of superoxide) but their toxic potential is controlled by their conversion to water by superoxide dismutase and glutathione peroxidase. It is the favorable redox potential of the $\mathrm{Fe}(\mathrm{II}) / \mathrm{Fe}(\mathrm{III})$ couple (between +0.35 and $-0.5 \mathrm{~V}$ ) that allows it to redox-cycle and thus to catalyze the interaction of superoxide with hydrogen peroxide $\left(\mathrm{H}_{2} \mathrm{O}_{2}\right)$ through the Haber-Weiss reaction, generating highly reactive hydroxyl free radicals $(\mathrm{OH}){ }^{42}$ The hydroxyl radical has a great affinity for electrons, will oxidize all substances within its immediate vicinity (diffusion radius of $2.3 \mathrm{~nm}),{ }^{42}$ and has been shown to promote lipid peroxidation, ${ }^{43,44}$ with damage to organelles such as lysosomes ${ }^{45}$ and mitochondria. ${ }^{46} 47$, The interaction of the hydroxyl radical with lipid proceeds though the initial abstraction of a hydrogen atom (to yield a water molecule), molecular rearrangement of the lipid with peroxidation, and the formation of a peroxyl radical which is able to propagate further lipid peroxidation in a chain reaction. The end result is decomposition of lipid molecules with concomitant effects on the integrity of organelles. While organelle damage may lead directly to apoptotic cell death, ${ }^{48,49}$ this may also encourage fibrogenesis as iron-induced aldehyde lipid peroxidation products such as MDA $^{50}$ and 4$\mathrm{HNE}^{51}$ promote collagen gene expression. Fibrogenesis is also associated with autocrine production of TGF $\beta-1$ in stellate cells ${ }^{52}$ (Figure 1). ROS also damage DNA, risking genomic instability, mutagenesis and cell death or neoplasia. ROS also directly activate caspases, thereby accelerating apoptosis, ${ }^{53}$ but, paradoxically, may also have anti-apoptotic effects by activating NF-kB, ${ }^{54}$ which may contribute to MDS transformation and to ironmediated neoplasia, such as hepatoma.

An important, often neglected, mechanism of toxicity from iron overload is that of the increased risk of infection, which is the second commonest cause of death in TM. Several mechanisms come into play, the most important being transferrin saturation. This protein, in addition to its pivotal role in supplying iron to the erythron and other tissues, naturally exists where only an average of $1 / 3$ of its two iron binding sites are occupied with $\mathrm{Fe}(\mathrm{III})$. A key role of $\mathrm{Tf}$ is to deprive bacteria of the iron that these microorganisms require 
to grow. While some bacteria have adapted to utilize transferrin iron, most have not, and so there is a paradigm shift in the availability of iron to microorganisms once transferrin becomes saturated. Other mechanisms, such as effects on neutrophil function have been postulated to be affected by $\mathrm{TIO}^{55}$ Recent work has shown that following blood transfusion, NTBI is liberated from the rapid catabolism of a proportion of non-viable red cells ${ }^{56}$. In principle, this and other forms of NTBI in plasma will be more available to microorganisms than transferrin iron.

\section{DISTRIBUTION AND CONSEQUENCES OF TIO}

\section{Iron distribution and consequences in Thalassemia Major}

The impact of chronic blood transfusion on body iron distribution is most completely described in TM, where transfusion typically begins in the first year of life. Transfused iron initially accumulates as storage iron in spleen, liver and BM macrophages and later in hepatocytes, with $80 \%$ of storage iron in the liver. The storage capacity of the macrophage system following blood transfusion has not been recently studied, but historical sources estimate it at about 10g. Histological descriptions using Perl's stain show that with increasing $\mathrm{TIO}$, increasing proportions are seen in hepatocytes once the macrophage system is saturated. Interestingly, particularly with optimal chelation therapy, TM patients today have low iron concentrations in hepatocytes while macrophage iron remains present ${ }^{57}$. This contrasts with NTDT where iron accumulates through the portal system and concentrates in peri-portal hepatocytes with macrophage sparing. This distribution in NTDT is thought to be influenced further by low hepcidin levels, and therefore high macrophage ferroportin, due to high levels of IE typical in thalassemia. ${ }^{57,58}$

As TIO evolves, particularly with sub-optimal chelation therapy, a variable proportion of iron 'escapes' from the liver into the endocrine tissues and heart. This gives rise to the classic pathology, morbidity and mortality historically associated with TIO. An understanding of the effects of blood transfusion on body iron distribution is best appreciated from post-mortem data obtained during pre-chelation era, ${ }^{59}$ because iron chelation fundamentally alters body iron distribution, being relatively tropic for hepatocellular iron compared with extra-hepatic iron. Data obtained under these circumstances showed that in patients dying from complications of TIO, iron was unevenly distributed in the body, with high concentrations present in liver, heart and endocrine tissues, very low in striated muscle and none in the brain. ${ }^{60}$ Remarkably, these patients typically died of heart failure in the second and third decades of life, although the myocardial iron concentration (MIC) was a fraction of that in the liver. This observation has recently been supported by MRI evidence; 61 examination of myocardial tissue both biochemically and by MRI at post mortem in patients dying from iron-induced cardiomyopathy showed an average MIC of only $5.98 \pm 2.42 \mathrm{mg} / \mathrm{g} \mathrm{dw}$. Evidently, the heart is less adapted to accommodating high concentrations of storage iron than the liver, even though the storage iron is not directly toxic to cells (see below). 
Prior to the introduction of cardiac MRI monitoring and newer chelation regimens, the frequency of heart failure, diabetes, hypothyroidism and hypoparathyroidism were all falling ${ }^{62}$. Hypogonadism (typically hypogonadotropic) is still an early and common feature of iron overload in TM, presenting with primary or secondary amenorrhea in females or poor growth and delayed puberty. ${ }^{62}$ Since the introduction of cardiac MRI imaging and the intensification of chelation therapy in selected patients with increased MIC ( $\left.\mathrm{mT}^{*}<20 \mathrm{~ms}\right)$, the incidence of heart failure has fallen further. Indeed in a recent cohort analysis of patients followed for a decade by cardiac MRI and receiving individually tailored chelation, heart failure was no longer the leading cause of death and the proportion of patients with myocardial iron (mT2* $<20 \mathrm{~ms}$ ) fell from $60 \%$ to $23 \%{ }^{63}$. Cirrhosis, which develops one or two decades after heart failure, is becoming more common as patients live longer, being present in about $50 \%$ of patients at post mortem and is particularly common in patients with chronic hepatitis. Similarly, hepatocellular carcinoma $^{64}$ is becoming more common.

The relationship between the accumulation of liver iron and the risk of extrahepatic spread has been the source of intense debate. Early work suggested a close relationship in TM between the control of LIC with deferoxamine and long-term outcome from cardiomyopathy ${ }^{65}$. Post mortem data in other diseases in the absence of chelation also suggested a relationship between transfusional iron load rate (ILR), LIC and MIC. ${ }^{66,67}$ When cardiac T2* became available in patients receiving a variety of chelation regimens, only a weak correlation between LIC and $\mathrm{mT}^{*}$ was seen, and it was argued therefore that control of LIC was not important to control of MIC in TM and therefore to limiting potentially fatal cardiomyopathy. ${ }^{68}$ The interpretation of the UCLH group was that this lack of correlation was mainly due to the high proportion of patients in this study having been on intensive chelation therapy with DFO, which was subsequently shown to decrease LIC at a faster rate than myocardial iron. ${ }^{68,69}$ This would therefore mask a potentially important relationship between these variables. Noetzli and colleagues ${ }^{70}$ have somewhat clarified this issue by demonstrating the importance of longitudinal rather than cross-sectional analysis of the relationship. They showed that failure to control LIC over several years with chelation increased the risk of myocardial iron deposition. Conversely, LIC reduction had a delayed effect on decreasing the MIC. Longitudinal UK studies of the LVEF relationship to $\mathrm{mT}^{*}$ show that the risk of heart failure increases for $\mathrm{mT}^{*}<10 \mathrm{~ms}{ }^{68}$, which approximates to MIC $>2.7 \mathrm{mg} / \mathrm{g} \mathrm{dw}{ }^{61}$. It can be concluded that LIC control in TM is important both to limiting liver damage and to controlling MIC, thus markedly reducing the risk of iron-mediated cardiomyopathy with heart failure.

\section{Iron distribution and consequences in sickle cell disease}

In patients receiving sufficient repeated transfusions to cause TIO, clinical consequences begin later than in TM, and thus effects on growth and sexual development are relatively uncommon. With transfusion, iron from erythrocyte catabolism initially accumulates in macrophages (Kupfer cells, sinusoidal compartment), but later, when the LIC exceeds $7 \mathrm{mg} / \mathrm{g} \mathrm{dw}$, in hepatocytes ${ }^{71}$ (based on the Angelucci formula ${ }^{72}$, being equivalent to about $5 \mathrm{~g}$ of transfused 
iron in a $70 \mathrm{~kg}$ adult, or about 25 units of transfused blood). Hepatocellular iron stores in SCD only approached those of the sinusoidal compartment when total liver iron levels were high $(>15 \mathrm{mg} / \mathrm{g} \mathrm{dw}$ or about 50 units of transfused red cells) ${ }^{71}$. Accumulation of liver iron without adequate chelation therapy risks fibrosis and cirrhosis, ${ }^{73}, 74,75$. Fibrosis has been reported as early as 2 years after initiation of transfusion and in about $1 / 3$ of patients with $\mathrm{LIC}>9 \mathrm{mg} / \mathrm{g} \mathrm{dw}$ and in direct proportion to the $\mathrm{LIC}^{75}$, correlating with $\mathrm{LIC}^{74}$ in the absence of hepatitis $C$ infection ${ }^{75}, 76$. The true frequency of cirrhosis in multi-transfused adult SCD patients is not clear. Post mortem studies found cirrhosis in $11 \%$ of all patients and in nearly half of patients who died with severe liver siderosis ${ }^{77}$.

The extra-hepatic consequences of iron overload, particularly endocrine and cardiac effects, appear to be later or more delayed in SCD than TM. Myocardial iron deposition judged by $\mathrm{T}^{*}$ is rare $^{78,79}$ and after more transfusion episodes in SCD than $\mathrm{TM}^{80}$. However, post-mortem studies show iron deposition in the heart in heavily transfused patients ${ }^{77}$. In SCD and TM patients matched for LIC, the incidence of heart disease, gonadal failure and endocrine disturbances including growth delay, appear to be less for age $<20$ years in $S C D^{81}$. Despite these differences from TM, SCD patients are unlikely to be completely protected from the extra-hepatic effects of TIO and indeed cases of myocardial iron are reported by $\mathrm{MRI}^{82}$. Recent preliminary studies from the Multi Center Study of Iron Overload (MCSIO) group found evidence of increased pituitary iron in SCD with highest $\mathrm{LIC}^{83}$. In one study patients with the lowest bone mass also had the highest serum iron values, although SF was within normal limits in these patients ${ }^{84}$. Furthermore there was an inverse correlation between the estimated pituitary iron and the pituitary volume, and hence its endocrine reserve. MRI may in principle identify early pituitary iron deposition in SCD before clinical manifestations are apparent. ${ }^{83}$

Increased iron has also been identified by MRI in the kidney. ${ }^{85}, 66$ This signal is highest in non-transfused patients with high levels of $\mathrm{LDH}$, lacks correlation with LIC and is higher than in TM patients, suggesting it originates from iron taken up by kidney from hemoglobin freed during intravascular hemolysis rather than iron delivered by transferrin or NTBI as a consequence of TIO. This also suggests that kidney R2* may be a biomarker for chronic hemolysis-mediated vascular complications in SCD. The extent to which this mechanism is implicated in renal damage in SCD is not clear.

\section{Iron distribution in other forms of TIO.}

TIO is seen in an increasing number of underlying conditions (Table 1). Iron accumulation in MDS may start even before patients become transfusiondependent because of IE, which although variably counterbalanced by increased levels of cytokines up-regulated during infections, e.g. IL-6, may still inhibit hepcidin production ${ }^{87}$ with subsequent increased iron absorption from the gut, as described earlier. Once transfusion begins, as with other forms of TIO, iron initially accumulates in RES and then in the liver. A key question with respect to the pathophysiology of iron overload is how rapidly iron spreads extra-hepatically and how rapidly this is likely to be problematic and hence require chelation treatment. In the pre-chelation era, patients 
examined at post mortem had an increased risk of myocardial iron with increasing numbers of blood transfusions ${ }^{66}$. Early studies with cardiac MRI showed and increasing risk of myocardial iron as the number of transfusions exceeded 50 units ${ }^{88,89}$. Analysis of the relationship between transfusion and myocardial iron is complicated since patients have received chelation therapy in some but not all reports. Overall, in non-chelated MDS patients, iron spread to myocardium occurs after approximately 70-100 units of blood (containing 14-20g iron). ${ }^{66,88}$

The prognostic impact of the resulting moderate degree of iron overload ${ }^{87}$ for overall survival is not clear because it is difficult to clearly separate the effects of TIO from other co-morbidities associated with BM failure without prospective controlled data. The prognostic importance of transfusion dependency for overall survival in patients with Low- and Intermediate-1-risk MDS has been examined in a retrospective analysis of European MDS and AML registry data, ${ }^{90}$ which showed that patients with $>20$ units transfused had a higher mortality rate $(30 \%)$ within 2 years of diagnosis than transfusionindependent patients (5\%). Among 705 patients followed for 2 years or until death, cardiac comorbidities were seen in $79 \%$ of chronically transfused patients versus only $54 \%$ of non-transfused MDS patients and $42 \%$ of a Medicare control population ${ }^{91}$ Although some retrospective data suggest a prognostic advantage to chelation therapy in MDS, ${ }^{92-95}$ this has not yet been reported in prospective studies. It is clear that response with iron balance to chelation is similar to other forms of TIO. Improved hematopoiesis has been observed in $20 \%$ of patients receiving deferasirox for 1 year. ${ }^{96}$ Responders showed a greater decrease in serum ferritin levels, suggesting that removal of iron from the BM plays a role in hematologic improvement.

There are a large number of disparate anemias that require chronic blood transfusion (Table 1). Patient numbers reported are insufficient to draw clear conclusions about whether the risks of TIO differ from those of TM. DBA is perhaps the most common of the rare anemias, but this is a heterogeneous group of conditions with a presumed shared pathology of ribosomal protein dysfunction. Recent work by the MCSIO group suggests transfused DBA patients are particularly susceptible to the extra-hepatic consequences of iron overload (Porter 2014, in preparation). The mechanisms and implications are discussed below.

\section{MECHANISMS UNDERLYING DISTRIBUTION OF TRANSFUSED IRON}

Because the distribution of storage iron appears to be key to the pathophysiology of TIO, some of the putative mechanisms determining this distribution will be considered further.

Transferrin iron is delivered to tissues expressing TfR1 in a controlled way through receptor-mediated endocytosis. The expression of TfR and hence iron acquisition from transferrin depends on iron homeostatic mechanisms (see above). The erythron and hepatocytes are rich in these receptors as are 
cells undergoing proliferation where its expression is cell cycle dependent. As iron overload develops, transferrin becomes increasingly saturated, with the eventual appearance of NTBI, typically when TfSat $>75 \% .^{97,98}$ The uptake of NTBI is less regulated than uptake from $\mathrm{Tf}$ and the distribution is also substantially different. ${ }^{99,100}$ This may account for the pattern of iron deposition, and hence its toxicity in advanced TIO. In experimental models, NTBI is rapidly taken up by hepatocytes ${ }^{101}$ and myocytes. ${ }^{102}$ In cultured heart cells, NTBI species are taken up at 200 times the rate of transferrin iron and generate free radicals, lipid peroxidation, organelle dysfunction and abnormal rhythmicity. ${ }^{102}{ }^{46}$ L-type calcium channels ${ }^{99}$, and zinc transporters ${ }^{103}$ have been implicated in NTBI uptake which appears to be restricted to tissues known to accumulate iron. Plasma NTBI (or its sub-fractions) can also promote lipid peroxidation through the generation of free radicals ${ }^{104}$ and associate with depletion of plasma anti-oxidants. ${ }^{105}$

The presumed relationship between NTBI levels and extra-hepatic iron distribution has not been convincingly demonstrated clinically. A weak correlation between NTBI and $\mathrm{mT2}^{*}$ was reported by Piga in TM patients ${ }^{106}$. However a careful analysis of NTBI levels in TM patients at UCLH has failed to find such an association (unpublished data), suggesting that the NTBI species heterogeneity may in principle affect the pattern of tissue iron uptake. NTBI species consist of iron citrate monomers, oligomers and polymers, as well as protein bound forms and these may differ in their rates of uptake into tissues $^{107,108}$. The various assays used to quantitate NTBI may measure different species that have variable importance to tissue iron uptake. It is not yet clear which assay is most appropriate to predicting extra-hepatic iron distribution. The classic NTBI assay captures both directly chelatable iron, as well as a fraction of iron species that are only slowly chelatable. ${ }^{108,109}$ Furthermore, the assay detects iron chelates of deferiprone ${ }^{110}$ or deferasirox. ${ }^{111}$ The LPI assay measures a fraction of NTBI that is redox-active and that is removed by the presence of iron chelators in plasma. The effect of iron chelate complexes is not clear but likely to affect this assay less than the NTBI assay. New assays for NTBI species are under development with the intention of obtaining an assay that has clear utility for predicting the risks of extra-hepatic iron distribution.

A further reason why NTBI levels are difficult to link precisely to extra-hepatic iron distribution is that NTBI is generated by factors other than iron overload. Two identified factors that generate NTBI are low levels of erythropoiesis and/or IE. Suppression of erythropoiesis, e.g. following myeloablative chemotherapy, leads to decreased clearance of transferrin iron and the rapid appearance of $\mathrm{NTBI},{ }^{113}$ which is quickly reversed following regeneration of erythropoiesis. In DBA, where recent work shows an absence of soluble transferrin receptors and hence of clearance of Tf iron by the erythron, NTBI iron levels are particularly high and this condition is associated with a high propensity to myocardial iron accumulation (Porter 2014, in preparation). Conversely, a high utilization of transferrin iron such as in the highly expanded erythron in NTDT would de-saturate small concentrations of transferrin, which in turn could inhibit NTBI iron uptake into target tissue. This effect would also be active in TM patients where the transfusion regimen 
does not completely suppress erythropoiesis. This hypothesis is currently under investigation (Garbowski 2014, in preparation).

Patients with SCD have low levels of NTBI ${ }^{112,113}$ and $\mathrm{LPI}^{114,115}$ compared with TM patients with similar levels of iron overload. It is an attractive hypothesis to link the low propensity for extra-hepatic iron distribution in SCD to this observation. Of note LPI is also low in SCD relative to other forms of TIO at similar levels of iron loading. However patients with NTDT have high levels of $\mathrm{NTBI}^{116,117}$ and $\mathrm{LPI}^{118}$ but a very low risk of myocardial iron, ${ }^{119}$ suggesting that absolute NTBI levels are not the only consideration. When a comparison of LPI in rare anemias resulting from hemolysis or from decreased red cell production was made, ${ }^{120}$ both were associated with raised LPI, which was removed following chelation therapy. Analysis of the same patients showed a significant correlation of LPI levels with both the degree of iron overload (ferritin) and transfusional ILR (Figure 2). This would support the notion that with increasing transfusional ILR, LPI and possibly the potential to extrahepatic iron loading increases. A systematic study of the relationship of transfusional loading rate, NTBI speciation and extra-hepatic complications of iron overload is warranted. 


\section{KEY POINTS}

- The pathophysiological consequences of TIO are best understood in TM and broadly reflect the distribution of excess storage iron to heart, endocrine tissues and liver.

- The pattern of excess iron distribution reflects the pattern of NTBI uptake to these tissues.

- Storage iron does not directly damage cells but its intracellular turnover contributes to labile intracellular iron pools that generate harmful free radicals

- TIO also increases the risk of infection, due to increased availability of labile iron to microorganisms

- In other conditions such as SCD, DBA and MDS the propensity to the extra-hepatic iron distribution and its consequences vary compared with TM

- The mechanisms underlining this variability may reflect differences in the transfusional iron loading rates, age of commencing transfusion as well as differences between transferrin iron utilization and NTBI generation. 
1. JACOBS A. THE PATHOLOGY OF IRON OVERLOAD IN: IRON IN BIOCHEMISTRY AND MEDICINE. LONDON: ACADEMIC PRESS; 1974.

2. BOTHWELL T, CHARLTON RW, COOK JD, FINCH CA. IRON METABOLISM IN MAN. OXFORD: BLACKWELL; 1979.

3. NEMETH E, GANZ T. REGULATION OF IRON METABOLISM BY HEPCIDIN. ANNU REV NUTR. 2006;26:323-342.

4. MASTROGIANNAKI M, MATAK P, KEITH B, SIMON MC, VAULONT S, PEYSSONNAUX C. HIF-2ALPHA, BUT NOT HIF-1ALPHA, PROMOTES IRON ABSORPTION IN MICE. THE JOURNAL OF CLINICAL INVESTIGATION. 2009;119(5):1159-1166.

5. NEMETH E, TUTTLE MS, POWELSON J, ET AL. HEPCIDIN REGULATES CELLULAR IRON EFFLUX BY BINDING TO FERROPORTIN AND INDUCING ITS INTERNALIZATION. SCIENCE. 2004;306(5704):20902093.

6. DELABY C, PILARD N, GONCALVES AS, BEAUMONT C, CANONNE-HERGAUX F. PRESENCE OF THE IRON EXPORTER FERROPORTIN AT THE PLASMA MEMBRANE OF MACROPHAGES IS ENHANCED BY IRON LOADING AND DOWN-REGULATED BY HEPCIDIN. BLOOD. 2005;106(12):3979-3984.

7. GANZ T. HEPCIDIN AND IRON REGULATION, 10 YEARS LATER. BLOOD. 2011;117(17):4425-4433.

8. DARSHAN D, ANDERSON GJ. INTERACTING SIGNALS IN THE CONTROL OF HEPCIDIN EXPRESSION. BIOMETALS. 2009;22(1):77-87.

9. TANNO T, BHANU NV, ONEAL PA, ET AL. HIGH LEVELS OF GDF15 IN THALASSEMIA SUPPRESS EXPRESSION OF THE IRON REGULATORY PROTEIN HEPCIDIN. NAT MED. 2007;13(9):1096-1101.

10. TANNO T, PORAYETTE P, SRIPICHAI O, ET AL. IDENTIFICATION OF TWSG1 AS A SECOND NOVEL ERYTHROID REGULATOR OF HEPCIDIN EXPRESSION IN MURINE AND HUMAN CELLS. BLOOD. 2009;114(1):181-186.

11. BIOIRON ABSTRACTS. AM J HEMATOL. 2013;88(5):E5-E243.

12. WILKINS SJ, FRAZER DM, MILLARD KN, MCLAREN GD, ANDERSON GJ. IRON METABOLISM IN THE HEMOGLOBIN-DEFICIT MOUSE: CORRELATION OF DIFERRIC TRANSFERRIN WITH HEPCIDIN EXPRESSION. BLOOD. 2006;107(4):1659-1664.

13. NEMETH E, VALORE EV, TERRITO M, SCHILLER G, LICHTENSTEIN A, GANZ T. HEPCIDIN, A PUTATIVE MEDIATOR OF ANEMIA OF INFLAMMATION, IS A TYPE II ACUTE-PHASE PROTEIN. BLOOD. 2002;14:14.

14. PAK $M$, LOPEZ MA, GABAYAN V, GANZ T, RIVERA S. SUPPRESSION OF HEPCIDIN DURING ANEMIA REQUIRES ERYTHROPOIETIC ACTIVITY. BLOOD. 2006;108(12):3730-3735.

15. FRAZER DM, WILKINS SJ, DARSHAN D, BADRICK AC, MCLAREN GD, ANDERSON GJ. STIMULATED ERYTHROPOIESIS WITH SECONDARY IRON LOADING LEADS TO A DECREASE IN HEPCIDIN DESPITE AN INCREASE IN BONE MORPHOGENETIC PROTEIN 6 EXPRESSION. BR J HAEMATOL. 2012;157(5):615-626. 
16. VOKURKA M, KRIJT J, SULC K, NECAS E. HEPCIDIN MRNA LEVELS IN MOUSE LIVER RESPOND TO INHIBITION OF ERYTHROPOIESIS. PHYSIOL RES. 2006;55(6):667-674.

17. LASOCKI S, MILLOT S, ANDRIEU V, ET AL. PHLEBOTOMIES OR ERYTHROPOIETIN INJECTIONS ALLOW MOBILIZATION OF IRON STORES IN A MOUSE MODEL MIMICKING INTENSIVE CARE ANEMIA. CRIT CARE MED. 2008;36(8):2388-2394.

18. ROUAULT T, STOUT C, KAPTAIN S, HARFORD J, KLAUSNER R. STRUCTURAL RELATIONSHIP BETWEEN AN IRON-REGULATED RNA BINDING PROTEIN (IRE-BP) AND ACONITASE: FUNCTIONAL IMPLICATIONS. CELL. 1991;64:881-883.

19. COOPERMAN SS, MEYRON-HOLTZ EG, OLIVIERRE-WILSON H, GHOSH MC, MCCONNELL JP, ROUAULT TA. MICROCYTIC ANEMIA, ERYTHROPOIETIC PROTOPORPHYRIA, AND NEURODEGENERATION IN MICE WITH TARGETED DELETION OF IRON-REGULATORY PROTEIN 2. BLOOD. 2005;106(3):1084-1091.

20. TAKETANI S. AQUISITION, MOBILIZATION AND UTILIZATION OF CELLULAR IRON AND HEME: ENDLESS FINDINGS AND GROWING EVIDENCE OF TIGHT REGULATION. TOHOKU $J$ EXP MED. 2005;205(4):297-318.

21. DE DOMENICO I, WARD DM, DI PATTI MC, ET AL. FERROXIDASE ACTIVITY IS REQUIRED FOR THE STABILITY OF CELL SURFACE FERROPORTIN IN CELLS EXPRESSING GPI-CERULOPLASMIN. EMBO J. 2007;26(12):2823-2831.

22. HIDER RC, KONG XL. GLUTATHIONE: A KEY COMPONENT OF THE CYTOPLASMIC LABILE IRON POOL. BIOMETALS. 2011;24(6):11791187.

23. PORTER J. BLOOD TRANSFUSION: QUALITY AND SAFETY ISSUES IN THALASSEMIA, BASIC REQUIREMENTS AND NEW TRENDS. HEMOGLOBIN. 2009;33 SUPPL 1:S28-36.

24. CAZZOLA M, DE STEFANO P, PONCHIO L, ET AL. RELATIONSHIP BETWEEN TRANSFUSION REGIMEN AND SUPPRESSION OF ERYTHROPOIESIS IN BETA-THALASSAEMIA MAJOR. BR J HAEMATOL. 1995;89(3):473-478.

25. CAZZOLA M, BORGNA-PIGNATTI C, LOCATELLI F, PONCHIO L, BEGUIN Y, DE STEFANO P. A MODERATE TRANSFUSION REGIMEN MAY REDUCE IRON LOADING IN BETA- THALASSEMIA MAJOR WITHOUT PRODUCING EXCESSIVE EXPANSION OF ERYTHROPOIESIS. TRANSFUSION. 1997;37(2):135-140.

26. BARRY M, FLYNN D, LETSKY E, RISDON R. LONG TERM CHELATION THERAPY IN THALASSAEMIA: EFFECT ON LIVER IRON CONCENTRATION, LIVER HISTOLOGY AND CLINICAL PROGRESS. BR MED J. 1974;2:16-20.

27. KODURI PR. IRON IN SICKLE CELL DISEASE: A REVIEW WHY LESS IS BETTER. AM J HEMATOL. 2003;73(1):59-63.

28. SEARS DA, ANDERSON PR, FOY AL, WILLIAMS HL, CROSBY WH. URINARY IRON EXCRETION AND RENAL METABOLISM OF HEMOGLOBIN IN HEMOLYTIC DISEASES. BLOOD. 1966;28(5):708-725. 29. WASHINGTON R, BOGGS DR. URINARY IRON IN PATIENTS WITH SICKLE CELL ANAMIA. J LAB CLIN MED. 1975;86(1):17-23. 
30. KEEL SB, DOTY RT, YANG Z, ET AL. A HEME EXPORT PROTEIN IS REQUIRED FOR RED BLOOD CELL DIFFERENTIATION AND IRON HOMEOSTASIS. SCIENCE. 2008;319(5864):825-828.

31. ADAMS RJ, BRAMBILLA D. DISCONTINUING PROPHYLACTIC TRANSFUSIONS USED TO PREVENT STROKE IN SICKLE CELL DISEASE. N ENGL J MED. 2005;353(26):2769-2778.

32. ELLIOTT VICHINSKY M, FRANCOISE BERNAUDIN, MD2, GIAN LUCA FORNI, MD3*, RENEE GARDNER, MD4, KATHRYN HASSELL, MD5*, MATTHEW M. HEENEY, MD6, BABA INUSA, MD7, ABDULLAH KUTLAR, MD8*, PETER A. LANE, MD9, LIESL MATHIAS, MD10*, JOHN B. PORTER, MD11*, CAMERON K TEBBI, MD12*, FELICIA L. WILSON, MD13*, LOUIS GRIFFEL, MD14*, WEI DENG, PHD14*, VANESSA GIANNONE, BSN14* AND THOMAS D. COATES, MD15. LONG-TERM SAFETY AND EFFICACY OF DEFERASIROX (EXJADE®) IN TRANSFUSED PATIENTS WITH SICKLE CELL DISEASE TREATED FOR UP TO 5 YEARS . ASH. 2010.

33. PORTER JB, HUEHNS ER. TRANSFUSION AND EXCHANGE TRANSFUSION IN SICKLE CELL ANAEMIAS, WITH PARTICULAR REFERENCE TO IRON METABOLISM. ACTA HAEMATOL. 1987;78(23):198-205.

34. KIM HC, DUGAN NP, SILBER JH, ET AL. ERYTHROCYTAPHERESIS THERAPY TO REDUCE IRON OVERLOAD IN CHRONICALLY TRANSFUSED PATIENTS WITH SICKLE CELL DISEASE. BLOOD. 1994;83:1136-1142.

35. PORTER J, GALANELLO R, SAGLIO G, ET AL. RELATIVE RESPONSE OF PATIENTS WITH MYELODYSPLASTIC SYNDROMES AND OTHER TRANSFUSION-DEPENDENT ANAEMIAS TO DEFERASIROX (ICL670): A 1-YR PROSPECTIVE STUDY. EUR J HAEMATOL. 2008;80(2):168-176.

36. CECCARELLI D, GALLESI D, GIOVANNINI F, FERRALI M, MASINI A. RELATIONSHIP BETWEEN FREE IRON LEVEL AND RAT LIVER MITOCHONDRIAL DYSFUNCTION IN EXPERIMENTAL DIETARY IRON OVERLOAD. BIOCHEM BIOPHYS RES COMMUN. 1995;209(1):53-59.

37. BREUER W, EPSZTEJN S, MILLGRAM P, CABANTCHIK IZ. TRANSPORT OF IRON AND OTHER TRANSITION METALS INTO CELLS AS REVEALED BY A FLUORESCENT PROBE. AM $J$ PHYSIOL. 1995;268(6 PT 1):C1354-1361.

38. COOPER CE, LYNAGH GR, HOYES KP, HIDER RC, CAMMACK R, PORTER JB. THE RELATIONSHIP OF INTRACELLULAR IRON CHELATION TO THE INHIBITION AND REGENERATION OF HUMAN RIBONUCLEOTIDE REDUCTASE. J BIOL CHEM. 1996;271(34):2029120299.

39. COOPER CE, PORTER JB. RIBONUCLEOTIDE REDUCTASE, LIPOXYGENASE AND THE INTRACELLULAR LOW- MOLECULARWEIGHT IRON POOL. BIOCHEM SOC TRANS. 1997;25(1):75-80.

40. GALARIS D, SKIADA V, BARBOUTI A. REDOX SIGNALING AND CANCER: THE ROLE OF "LABILE" IRON. CANCER LETT. 2008;266(1):21-29. 
41. EPSZTEJN S, GLICKSTEIN H, PICARD V, ET AL. H-FERRITIN SUBUNIT OVEREXPRESSION IN ERYTHROID CELLS REDUCES THE OXIDATIVE STRESS RESPONSE AND INDUCES MULTIDRUG RESISTANCE PROPERTIES. BLOOD. 1999;94(10):3593-3603.

42. MARX JJM, VAN ASBECK BS. USE OF CHELATORS IN PREVENTING HYDROXYL RADICAL DAMAGE: ADULT RESPIRATORY DISTRESS SYNDROME AS AN EXPERIMENTAL MODEL FOR THE TREATMENT OF OXYGEN-RADICAL-MEDIATED TISSUE DAMAGE. ACTA HAEMATOLOGICA. 1996;95:49-62.

43. KORNBRUST DJ, MAVIS RD. MICROSOMAL LIPID PEROXIDATION. 1. CHARACTERISATION OF THE ROLE OF IRON AND NADPH. MOLECULAR PHARMACOLOGY. 1980;17:400-407.

44. BACON BR, TAVILL AS, BRITTENHAM GM, PARK CH, RECKNAGEL RO. HEPATIC LIPID PEROXIDATION IN VIVO IN RATS WITH CHRONIC IRON OVERLOAD. J CLIN INVEST. 1983;71(3):429-439.

45. MYERS BM, PRENDERGAST FG, HOLMAN R, KUNTZ SM, LARUSSO NF. ALTERATIONS IN THE STRUCTURE, PHYSICOCHEMICAL PROPERTIES, AND PH OF HEPATOCYTE LYSOSOMES IN EXPERIMENTAL IRON OVERLOAD. JOURNAL OF CLINICAL INVESTIGATION. 1991;88(4):1207-1215.

46. LINK G, PINSON A, HERSHKO C. IRON LOADING OF CULTURED CARDIAC MYOCYTES MODIFIES SARCOLEMMAL STRUCTURE AND INCREASES LYSOSOMAL FRAGILITY. J LAB CLIN MED. 1993;121(1):127-134.

47. LINK G, SAADA A, PINSON A, KONIJN AM, HERSHKO C. MITOCHONDRIAL RESPIRATORY ENZYMES ARE A MAJOR TARGET OF IRON TOXICITY IN RAT HEART CELLS. J LAB CLIN MED. 1998;131(5):466-474.

48. ZHAO $M$, LAISSUE JA, ZIMMERMANN A. HEPATOCYTE APOPTOSIS IN HEPATIC IRON OVERLOAD DISEASES. HISTOL HISTOPATHOL. 1997;12(2):367-374.

49. JACOB AK, HOTCHKISS RS, SWANSON PE, TINSLEY KW, KARL IE, BUCHMAN TG. INJECTION OF IRON COMPOUNDS FOLLOWED BY INDUCTION OF THE STRESS RESPONSE CAUSES TISSUE INJURY AND APOPTOSIS. SHOCK. 2000;14(4):460-464.

50. HOUGLUM K, FILIP M, WITZTUM JL, CHOJKIER M. MALONDIALDEHYDE AND 4-HYDROXYNONENAL PROTEIN ADDUCTS IN PLASMA AND LIVER OF RATS WITH IRON OVERLOAD. JOURNAL OF CLINICAL INVESTIGATION. 1990; 86(6):1991-1998.

51. PAROLA M, PINZANI A, CASINI E, ET AL. STIMULATION OF LIPID PEROXIDATION OR 4-HYDROXYNONENAL TREATMENT INCREASED PROCOLLAGEN (I) GENE EXPRESSION IN HUMAN FAT STORING CELLS. JOURNAL OF BIOLOGICAL CHEMISTRY. 1993;264:16957-16962. 52. BISSELL DM, WANG SS, JARNAGIN WR, ROLL FJ. CELL SPECIFIC EXPRESSION OF TRANSFORMING GROWTH FACTOR-ß IN THE RAT LIVER. JOURNAL OF CLINICAL INVESTIGATION. 1995;96:447455.

53. ZUO Y, XIANG B, YANG J, ET AL. OXIDATIVE MODIFICATION OF CASPASE-9 FACILITATES ITS ACTIVATION VIA DISULFIDE-MEDIATED INTERACTION WITH APAF-1. CELL RES. 2009;19(4):449-457. 
54. AGGARWAL BB. NUCLEAR FACTOR-KAPPAB: THE ENEMY WITHIN. CANCER CELL. 2004;6(3):203-208.

55. HOEPELMAN IM, BEZEMER WA, VAN DOORNMALEN E, VERHOEF J, MARX JJ. LIPID PEROXIDATION OF HUMAN GRANULOCYTES (PMN) AND MONOCYTES BY IRON COMPLEXES. BR J HAEMATOL. 1989;72(4):584-588.

56. HOD EA, ZHANG $N$, SOKOL SA, ET AL. TRANSFUSION OF RED BLOOD CELLS AFTER PROLONGED STORAGE PRODUCES HARMFUL EFFECTS THAT ARE MEDIATED BY IRON AND INFLAMMATION. BLOOD. 2010;115(21):4284-4292.

57. ORIGA $R$, GALANELLO $R$, GANZ T, ET AL. LIVER IRON CONCENTRATIONS AND URINARY HEPCIDIN IN BETA-THALASSEMIA. HAEMATOLOGICA. 2007;92(5):583-588.

58. KATTAMIS A, PAPASSOTIRIOU I, PALAIOLOGOU D, ET AL. THE EFFECTS OF ERYTHROPOETIC ACTIVITY AND IRON BURDEN ON HEPCIDIN EXPRESSION IN PATIENTS WITH THALASSEMIA MAJOR. HAEMATOLOGICA. 2006;91(6):809-812.

59. MODELL B. MANAGEMENT OF THALASSAEMIA MAJOR. BR MED BULL. 1976;32(3):270-276.

60. MODELL B, MATTHEWS R. THALASSEMIA IN BRITAIN AND AUSTRALIA. BIRTH DEFECTS ORIGINAL ARTICLE SERIES. 1976;12(8):13-29.

61. CARPENTER JP, HE T, KIRK P, ET AL. ON T2* MAGNETIC RESONANCE AND CARDIAC IRON. CIRCULATION. 2011;123(14):15191528.

62. BORGNA-PIGNATTI C, RUGOLOTTO S, DE STEFANO P, ET AL. SURVIVAL AND COMPLICATIONS IN PATIENTS WITH THALASSEMIA MAJOR TREATED WITH TRANSFUSION AND DEFEROXAMINE. HAEMATOLOGICA. 2004;89(10):1187-1193.

63. THOMAS AS, GARBOWSKI M, ANG AL, ET AL. A DECADE FOLLOW-UP OF A THALASSEMIA MAJOR (TM) COHORT MONITORED BY CARDIAC MAGNETIC RESONANCE IMAGING (CMR): SIGNIFICANT REDUCTION IN PATIENTS WITH CARDIAC IRON AND IN TOTAL MORTALITY. ASH ANNUAL MEETING ABSTRACTS. 2010;116(21):1011-.

64. BORGNA-PIGNATTI C, VERGINE G, LOMBARDO T, ET AL. HEPATOCELLULAR CARCINOMA IN THE THALASSAEMIA SYNDROMES. BR J HAEMATOL. 2004;124(1):114-117.

65. BRITTENHAM GM, GRIFFITH PM, NIENHUIS AW, ET AL. EFFICACY OF DEFEROXAMINE IN PREVENTING COMPLICATIONS OF IRON OVERLOAD IN PATIENTS WITH THALASSEMIA MAJOR [SEE COMMENTS]. N ENGL J MED. 1994;331(9):567-573.

66. BUJA LM, ROBERTS WC. IRON IN THE HEART. ETIOLOGY AND CLINICAL SIGNIFICANCE. AM J MED. 1971;51(2):209-221.

67. ST PIERRE TG, TRAN KC, WEBB J, ET AL. ORGAN-SPECIFIC CRYSTALLINE STRUCTURES OF FERRITIN CORES IN BETATHALASSEMIA/HEMOGLOBIN E. BIOL MET. 1991;4(3):162-165.

68. ANDERSON LJ, HOLDEN S, DAVIS B, ET AL. CARDIOVASCULAR T2-STAR (T2*) MAGNETIC RESONANCE FOR THE EARLY DIAGNOSIS OF MYOCARDIAL IRON OVERLOAD. EUR HEART J. 2001;22(23):21712179. 
69. ANDERSON LJ, WESTWOOD MA, HOLDEN S, ET AL. MYOCARDIAL IRON CLEARANCE DURING REVERSAL OF SIDEROTIC CARDIOMYOPATHY WITH INTRAVENOUS DESFERRIOXAMINE: A PROSPECTIVE STUDY USING T2* CARDIOVASCULAR MAGNETIC RESONANCE. BR J HAEMATOL. 2004;127(3):348-355.

70. NOETZLI LJ, CARSON SM, NORD AS, COATES TD, WOOD JC. LONGITUDINAL ANALYSIS OF HEART AND LIVER IRON IN THALASSEMIA MAJOR. BLOOD. 2008;112(7):2973-2978.

71. HANKINS JS, SMELTZER MP, MCCARVILLE MB, ET AL. PATTERNS OF LIVER IRON ACCUMULATION IN PATIENTS WITH SICKLE CELL DISEASE AND THALASSEMIA WITH IRON OVERLOAD. EUR J HAEMATOL. 2010;85(1):51-57.

72. ANGELUCCI E, BRITTENHAM GM, MCLAREN CE, ET AL. HEPATIC IRON CONCENTRATION AND TOTAL BODY IRON STORES IN THALASSEMIA MAJOR. N ENGL J MED. 2000;343(5):327-331.

73. COMER GM, OZICK LA, SACHDEV RK, ET AL. TRANSFUSIONRELATED CHRONIC LIVER DISEASE IN SICKLE CELL ANEMIA. AMERICAN JOURNAL OF GASTROENTEROLOGY. 1991;86(9):12321234.

74. HARMATZ P, BUTENSKY E, QUIROLO K, ET AL. SEVERITY OF IRON OVERLOAD IN PATIENTS WITH SICKLE CELL DISEASE RECEIVING CHRONIC RED BLOOD CELL TRANSFUSION THERAPY. BLOOD. 2000;96(1):76-79.

75. OLIVIERI NF. PROGRESSION OF IRON OVERLOAD IN SICKLE CELL DISEASE. SEMIN HEMATOL. 2001;38(1 SUPPL 1):57-62.

76. BROWN K, SUBRAMONY C, MAY W, ET AL. HEPATIC IRON OVERLOAD IN CHILDREN WITH SICKLE CELL ANEMIA ON CHRONIC TRANSFUSION THERAPY. JOURNAL OF PEDIATRIC HEMATOLOGY/ONCOLOGY. 2009;31(5):309-312.

77. DARBARI DS, KPLE-FAGET P, KWAGYAN J, RANA S, GORDEUK VR, CASTRO O. CIRCUMSTANCES OF DEATH IN ADULT SICKLE CELL DISEASE PATIENTS. AM J HEMATOL. 2006;81(11):858-863.

78. PORTER JB. CONCEPTS AND GOALS IN THE MANAGEMENT OF TRANSFUSIONAL IRON OVERLOAD. AM J HEMATOL. 2007;82(12 SUPPL):1136-1139.

79. WESTWOOD MA, SHAH F, ANDERSON LJ, ET AL. MYOCARDIAL TISSUE CHARACTERIZATION AND THE ROLE OF CHRONIC ANEMIA IN SICKLE CELL CARDIOMYOPATHY. J MAGN RESON IMAGING. 2007;26(3):564-568.

80. WOOD JC, TYSZKA JM, CARSON S, NELSON MD, COATES TD. MYOCARDIAL IRON LOADING IN TRANSFUSION-DEPENDENT THALASSEMIA AND SICKLE CELL DISEASE. BLOOD. 2004;103(5):19341936.

81. VICHINSKY E, BUTENSKY E, FUNG E, ET AL. COMPARISON OF ORGAN DYSFUNCTION IN TRANSFUSED PATIENTS WITH SCD OR BETA THALASSEMIA. AM J HEMATOL. 2005;80(1):70-74.

82. GLANVILLE J, ELEFTHERIOU P, PORTER J. MRI EVIDENCE OF CARDIAC IRON ACCUMULATION IN MYELODYSPLASIA AND UNUSUAL ANEMIAS. 
. BLOOD 2006108 (11):PAGE 446A ABSTRACT 1553.

83. WANG ZJ, WOOD J, WALTER P, ET AL. IRON DISTRIBUTION ASSESSED BY MRI IN SICKLE CELL DISEASE, THALASSEMIA AND DIAMOND BLACKFAN ANEMIA (MSCIO PILOT STUDY). AMERICAN JOURNAL OF HEMATOLOGY. 2013;88(5):E96, POSTER \#90.

84. SADAT-ALI M, SULTAN O, AL-TURKI H, ALELQ A. DOES HIGH SERUM IRON LEVEL INDUCE LOW BONE MASS IN SICKLE CELL ANEMIA ? BIOMETALS : AN INTERNATIONAL JOURNAL ON THE ROLE OF METAL IONS IN BIOLOGY, BIOCHEMISTRY, AND MEDICINE. 2011;24(1):19-22.

85. SCHEIN A, ENRIQUEZ C, COATES TD, WOOD JC. MAGNETIC RESONANCE DETECTION OF KIDNEY IRON DEPOSITION IN SICKLE CELL DISEASE: A MARKER OF CHRONIC HEMOLYSIS. JOURNAL OF MAGNETIC RESONANCE IMAGING : JMRI. 2008;28(3):698-704.

86. VASAVDA N, GUTIERREZ L, HOUSE MJ, DRASAR E, ST PIERRE TG, THEIN SL. RENAL IRON LOAD IN SICKLE CELL DISEASE IS INFLUENCED BY SEVERITY OF HAEMOLYSIS. BRITISH JOURNAL OF HAEMATOLOGY. 2012;157(5):599-605.

87. SANTINI V, GIRELLI D, SANNA A, ET AL. HEPCIDIN LEVELS AND THEIR DETERMINANTS IN DIFFERENT TYPES OF MYELODYSPLASTIC SYNDROMES. PLOS ONE. 2011;6(8):E23109.

88. JENSEN PD, JENSEN FT, CHRISTENSEN T, EISKJAER $H$, BAANDRUP U, NIELSEN JL. EVALUATION OF MYOCARDIAL IRON BY MAGNETIC RESONANCE IMAGING DURING IRON CHELATION THERAPY WITH DEFERRIOXAMINE: INDICATION OF CLOSE RELATION BETWEEN MYOCARDIAL IRON CONTENT AND CHELATABLE IRON POOL. BLOOD. 2003;101(11):4632-4639.

89. JAEGER M, AUL C, SOHNGEN D, GERMING U, SCHNEIDER W. [SECONDARY HEMOCHROMATOSIS IN POLYTRANSFUSED PATIENTS WITH MYELODYSPLASTIC SYNDROMES]. BEITR INFUSIONSTHER. 1992;30:464-468.

90. DE SWART L, SMITH A, FENAUX P, ET AL. TRANSFUSIONDEPENDENCY IS THE MOST IMPORTANT PROGNOSTIC FACTOR FOR SURVIVAL IN 1000 NEWLY DIAGNOSED MDS PATIENTS WITH LOWAND INTERMEDIATE-1 RISK MDS IN THE EUROPEAN LEUKEMIANET MDS REGISTRY. ASH ANNUAL MEETING ABSTRACTS. 2011;118(21):2775-.

91. GOLDBERG SL, CHEN E, CORRAL M, ET AL. INCIDENCE AND CLINICAL COMPLICATIONS OF MYELODYSPLASTIC SYNDROMES AMONG UNITED STATES MEDICARE BENEFICIARIES. J CLIN ONCOL. 2010;28(17):2847-2852.

92. LEITCH HA, LEGER CS, GOODMAN TA, ET AL. IMPROVED SURVIVAL IN PATIENTS WITH MYELODYSPLASTIC SYNDROME RECEIVING IRON CHELATION THERAPY. CLINICAL LEUKEMIA. 2008;2(3):205-211. 
93. ROSE C, BRECHIGNAC S, VASSILIEF D, ET AL. DOES IRON CHELATION THERAPY IMPROVE SURVIVAL IN REGULARLY TRANSFUSED LOWER RISK MDS PATIENTS? A MULTICENTER STUDY BY THE GFM. LEUKEMIA RESEARCH. 2010;34(7):864-870.

94. FOX F, KUNDGEN A, NACHTKAMP K, ET AL. MATCHED-PAIR ANALYSIS OF 186 MDS PATIENTS RECEIVING IRON CHELATION THERAPY OR TRANSFUSION THERAPY ONLY. ASH ANNUAL MEETING ABSTRACTS. 2009;114(22):1747-.

95. KOMROKJI RS, ALI NHA, PADRON E, LANCET JE, LIST AF. IMPACT OF IRON CHELATION THERAPY ON OVERALL SURVIVAL AND AML TRANSFORMATION IN LOWER RISK MDS PATIENTS TREATED AT THE MOFFITT CANCER CENTER. ASH ANNUAL MEETING ABSTRACTS. 2011;118(21):2776-.

96. GATTERMANN $N$, FINELLI C, DELLA PORTA $M$, ET AL. HEMATOLOGIC RESPONSES TO DEFERASIROX THERAPY IN TRANSFUSION-DEPENDENT PATIENTS WITH MYELODYSPLASTIC SYNDROMES. HAEMATOLOGICA. 2012;97(9):1364-1371.

97. LE LAN C, LOREAL O, COHEN T, ET AL. REDOX ACTIVE PLASMA IRON IN C282Y/C282Y HEMOCHROMATOSIS. BLOOD. 2005;105(11):4527-4531.

98. LOREAL O, GOSRIWATANA I, GUYADER D, PORTER J, BRISSOT $P$, HIDER RC. DETERMINATION OF NON-TRANSFERRIN-BOUND IRON IN GENETIC HEMOCHROMATOSIS USING A NEW HPLC-BASED METHOD. J HEPATOL. 2000;32(5):727-733.

99. OUDIT GY, SUN H, TRIVIERI MG, ET AL. L-TYPE CA2+ CHANNELS PROVIDE A MAJOR PATHWAY FOR IRON ENTRY INTO CARDIOMYOCYTES IN IRON-OVERLOAD CARDIOMYOPATHY. NAT MED. 2003;9(9):1187-1194.

100. OUDIT GY, TRIVIERI MG, KHAPER N, LIU PP, BACKX PH. ROLE OF L-TYPE CA2+ CHANNELS IN IRON TRANSPORT AND IRONOVERLOAD CARDIOMYOPATHY. J MOL MED. 2006;84(5):349-364.

101. BRISSOT $P$, WRIGHT TL, MA WL, WEISIGER RA. EFFICIENT CLEARANCE OF NON-TRANSFERRIN-BOUND IRON BY RAT LIVER. IMPLICATIONS FOR HEPATIC IRON LOADING IN IRON OVERLOAD STATES. J CLIN INVEST. 1985;76(4):1463-1470.

102. LINK G, PINSON A, KAHANE I, HERSHKO C. IRON LOADING MODIFIES THE FATTY ACID COMPOSITION OF CULTURED RAT MYOCARDIAL CELLS AND LIPOSOMAL VESICLES: EFFECT OF ASCORBATE AND ALPHA-TOCOPHEROL ON MYOCARDIAL LIPID PEROXIDATION. JOURNAL OF LABORATORY AND CLINICAL MEDICINE. 1989;114:243-249.

103. LIUZZI JP, AYDEMIR F, NAM H, KNUTSON MD, COUSINS RJ. ZIP14 (SLC39A14) MEDIATES NON-TRANSFERRIN-BOUND IRON UPTAKE INTO CELLS. PROC NATL ACAD SCI $U$ S $A$. 2006;103(37):13612-13617.

104. GUTTERIDGE J, ROWLEY D, GRIFFITHS E, HALLIWELL B. LOW MOLECULAR WEIGHT IRON COMPLEXES AND OXYGEN RADICAL REACTIONS IN IDIOPATHIC HAEMOCHROMATOSIS. CLIN SCI. 1985;68:463-467. 
105. DE LUCA C, FILOSA A, GRANDINETTI M, MAGGIO F, LAMBA M, PASSI S. BLOOD ANTIOXIDANT STATUS AND URINARY LEVELS OF CATECHOLAMINE METABOLITES IN BETA-THALASSEMIA. FREE RADIC RES. 1999;30(6):453-462.

106. PIGA A, LONGO F, DUCA L, ET AL. HIGH NONTRANSFERRIN BOUND IRON LEVELS AND HEART DISEASE IN THALASSEMIA MAJOR. AM J HEMATOL. 2009;84(1):29-33.

107. GROOTVELD M, BELL JD, HALLIWELL B, ARUOMA OI, BOMFORD A, SADLER PJ. NON-TRANSFERRIN-BOUND IRON IN PLASMA OR SERUM FROM PATIENTS WITH IDIOPATHIC HEMOCHROMATOSIS. CHARACTERIZATION BY HIGH PERFORMANCE LIQUID CHROMATOGRAPHY AND NUCLEAR MAGNETIC RESONANCE SPECTROSCOPY. J BIOL CHEM. 1989;264(8):4417-4422.

108. EVANS RW, RAFIQUE R, ZAREA A, ET AL. NATURE OF NONTRANSFERRIN-BOUND IRON: STUDIES ON IRON CITRATE COMPLEXES AND THALASSEMIC SERA. J BIOL INORG CHEM. 2008;13(1):57-74.

109. EVANS P, KAYYALI R, HIDER RC, ECCLESTON J, PORTER JB. MECHANISMS FOR THE SHUTTLING OF PLASMA NON-TRANSFERRINBOUND IRON (NTBI) ONTO DEFEROXAMINE BY DEFERIPRONE. TRANSL RES. 2010;156(2):55-67.

110. AYDINOK Y, EVANS P, MANZ CY, PORTER JB. TIMED NONTRANSFERRIN BOUND IRON DETERMINATIONS PROBE THE ORIGIN OF CHELATABLE IRON POOLS DURING DEFERIPRONE REGIMENS AND PREDICT CHELATION RESPONSE. HAEMATOLOGICA. 2012;97(6):835-841.

111. LAL A, PORTER J, SWEETERS N, ET AL. COMBINED CHELATION THERAPY WITH DEFERASIROX AND DEFEROXAMINE IN THALASSEMIA. BLOOD CELLS, MOLECULES, AND DISEASES. 2013;50(2):99-104.

112. WALTER PB, FUNG EB, KILLILEA DW, ET AL. OXIDATIVE STRESS AND INFLAMMATION IN IRON-OVERLOADED PATIENTS WITH BETA-THALASSAEMIA OR SICKLE CELL DISEASE. BR J HAEMATOL. 2006;135(2):254-263.

113. SHAH F, WESTWOOD MA, EVANS PJ, PORTER JB. DISCORDANCE IN MRI ASSESSMENT OF IRON DISTRIBUTION AND PLASMA NTBI BETWEEN TRANSFUSIONALLY IRON LOADED ADULTS WITH SICKLE CELL AND THALASSAEMIA SYNDROMES. . BLOOD 2002;100:468A.

114. KOREN A, FINK D, ADMONI O, TENNENBAUM-RAKOVER Y, LEVIN C. NON-TRANSFERRIN-BOUND LABILE PLASMA IRON AND IRON OVERLOAD IN SICKLE-CELL DISEASE: A COMPARATIVE STUDY BETWEEN SICKLE-CELL DISEASE AND BETA-THALASSEMIC PATIENTS. EUROPEAN JOURNAL OF HAEMATOLOGY. 2010;84(1):7278.

115. GHOTI H, GOITEIN O, KOREN A, ET AL. NO EVIDENCE FOR MYOCARDIAL IRON OVERLOAD AND FREE IRON SPECIES IN MULTITRANSFUSED PATIENTS WITH SICKLE/BETA-THALASSAEMIA. EUR J HAEMATOL. 2010;84(1):59-63. 
116. TAHER A, MUSALLAM KM, EL RASSI F, ET AL. LEVELS OF NONTRANSFERRIN-BOUND IRON AS AN INDEX OF IRON OVERLOAD IN PATIENTS WITH THALASSAEMIA INTERMEDIA. BR J HAEMATOL. 2009;146(5):569-572.

117. PORTER J CM, KATTAMIS A, VIPRAKASIT V, LAWNICZEK T, ROS J, DENG W, TAHER A. RELATIONSHIPS BETWEEN PLASMA NONTRANSFERRIN-BOUND IRON AND MARKERS OF IRON OVERLOAD, ANAEMIA AND INEFFECTIVE ERYTHROPOIESIS IN NONTRANSFUSION-DEPENDENT THALASSAEMIA SYNDROMES. HAEMATOLOGICA 2011;96:228:ABSTRACT \#0536. 16TH CONGRESS OF THE EUROPEAN HEMATOLOGY ASSOCIATION, LONDON, UNITED KINGDOM, JUNE 9-12, 2011. HAEMATOLOGICA. 2011;96(SUPPLEMENT 2):1-678.

118. POOTRAKUL $P$, BREUER $W$, SAMETBAND $M$, SIRANKAPRACHA P, HERSHKO C, CABANTCHIK ZI. LABILE PLASMA IRON (LPI) AS AN INDICATOR OF CHELATABLE PLASMA REDOX ACTIVITY IN IRONOVERLOADED BETA-THALASSEMIA/HBE PATIENTS TREATED WITH AN ORAL CHELATOR. BLOOD. 2004;104(5):1504-1510.

119. ORIGA $R$, BARELLA $S$, ARGIOLAS GM, BINA P, AGUS A, GALANELLO R. NO EVIDENCE OF CARDIAC IRON IN 20 NEVER- OR MINIMALLY-TRANSFUSED PATIENTS WITH THALASSEMIA INTERMEDIA. HAEMATOLOGICA. 2008;93(7):1095-1096.

120. PORTER JB, LIN KH, BERIS P, ET AL. RESPONSE OF IRON OVERLOAD TO DEFERASIROX IN RARE TRANSFUSION-DEPENDENT ANAEMIAS: EQUIVALENT EFFECTS ON SERUM FERRITIN AND LABILE PLASMA IRON FOR HAEMOLYTIC OR PRODUCTION ANAEMIAS. EUR J HAEMATOL. 2011;87(4):338-348.

121. WICKRAMASINGHE SN, THEIN SL, SRICHAIRATANAKOOL S, PORTER JB. DETERMINANTS OF IRON STATUS AND BILIRUBIN LEVELS IN CONGENITAL DYSERYTHROPOIETIC ANAEMIA TYPE I. BR J HAEMATOL. 1999;107(3):522-525.

122. OHNUMA K, TOYODA Y, NISHIHIRA H, ET AL. [DETECTION OF EARLY CARDIAC DYSFUNCTION IN PATIENTS WITH TRANSFUSIONDEPENDENT APLASTIC ANEMIA AND CHRONIC IRON OVERLOAD IN CHILDHOOD. STRESS-VELOCITY RELATION AS A SENSITIVE INDEX BY ECHOCARDIOGRAPHY]. RINSHO KETSUEKI. 1996;37(9):825-832.

123. KIM KH, KIM JW, RHEE JY, ET AL. COST ANALYSIS OF IRONRELATED COMPLICATIONS IN A SINGLE INSTITUTE. KOREAN J INTERN MED. 2009;24(1):33-36.

124. TAKATOKU M, UCHIYAMA T, OKAMOTO $S$, ET AL. RETROSPECTIVE NATIONWIDE SURVEY OF JAPANESE PATIENTS WITH TRANSFUSION-DEPENDENT MDS AND APLASTIC ANEMIA HIGHLIGHTS THE NEGATIVE IMPACT OF IRON OVERLOAD ON MORBIDITY/MORTALITY. EUR J HAEMATOL. 2007;78(6):487-494.

125. LEE JW. IRON CHELATION THERAPY IN THE MYELODYSPLASTIC SYNDROMES AND APLASTIC ANEMIA: A REVIEW OF EXPERIENCE IN SOUTH KOREA. INT J HEMATOL. 2008;88(1):16-23. 


\section{FIGURES}

Figure 1

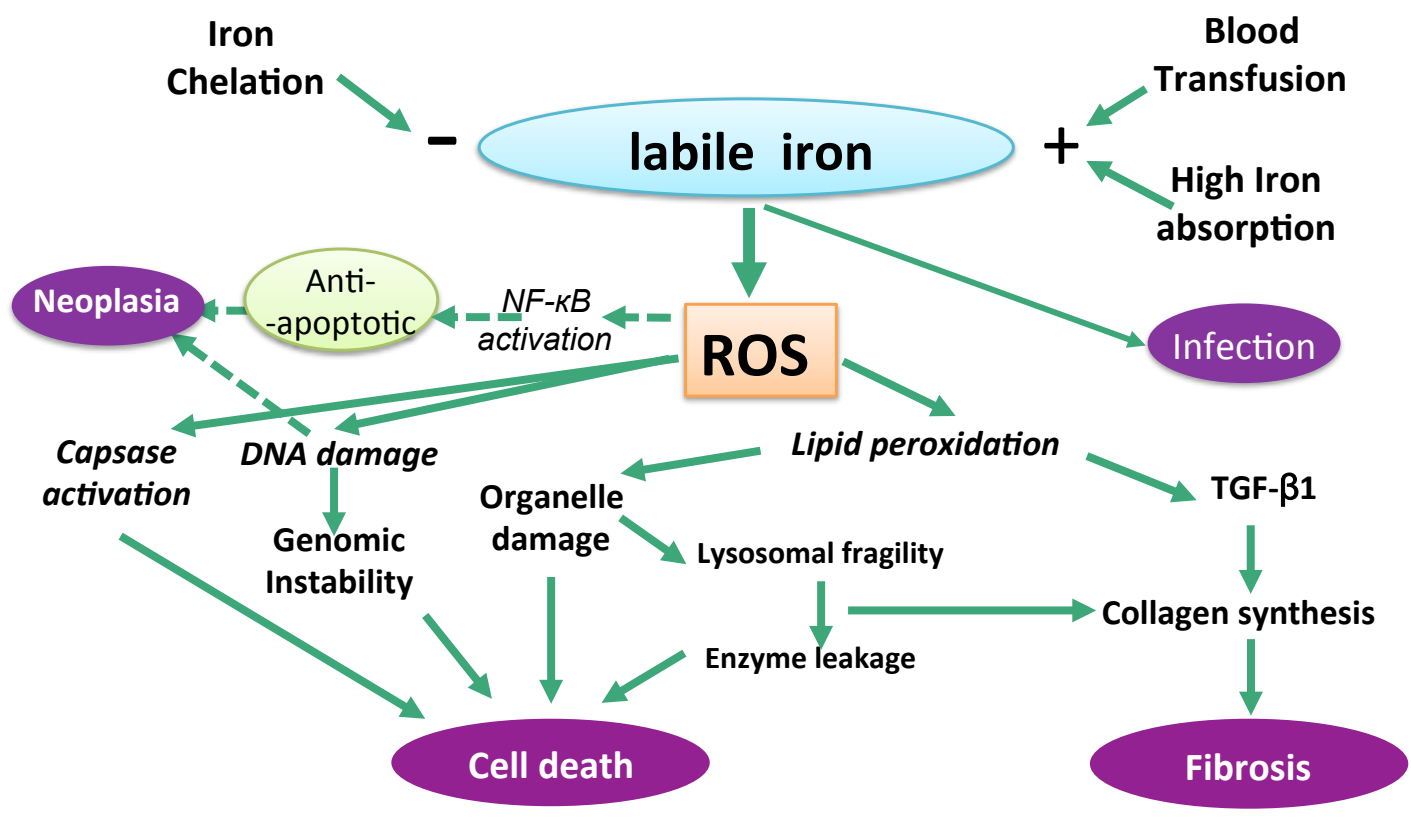

Adapted from Porter JB. Hematol Oncol Clin North Am. 2005;19(suppl 1):7-12

Figure 1. Pathological mechanisms and consequences of iron overload. In iron overload resulting from repeated blood transfusions or long-term increased iron absorption, iron that is not liganded to naturally occurring molecules such as transferrin or ferritin or to therapeutic iron chelators, generates a variety of reactive oxygen species (ROS), most notably hydroxyl radicals. This occurs in cells where labile plasma iron is accumulated (especially liver, endocrine tissues and myocardium) thereby increasing levels of both storage and labile cellular iron. ROS increase lipid peroxidation and organelle damage, leading to cell death and fibrogenesis mediated by transforming growth factor, TGF $\beta$ 1. (Porter JB. Hematol Oncol Clin North Am. 2005;19(suppl 1):7-12,) ROS also damage DNA, risking genomic instability, mutagenesis and cell death or neoplasia. ROS directly activates caspases thereby accelerating apoptotic death (Zuo Y, et al. Cell Res. 2009;19:449-57). Paradoxically, ROS may also have anti-apoptotic effects by activating NF-kB (dashed lines) (Aggarwal BB. Cancer Cell. 2004;6:203-8.) which may contribute to MDS transformation and to iron mediated neoplasia such as hepatoma. 
Figure 2
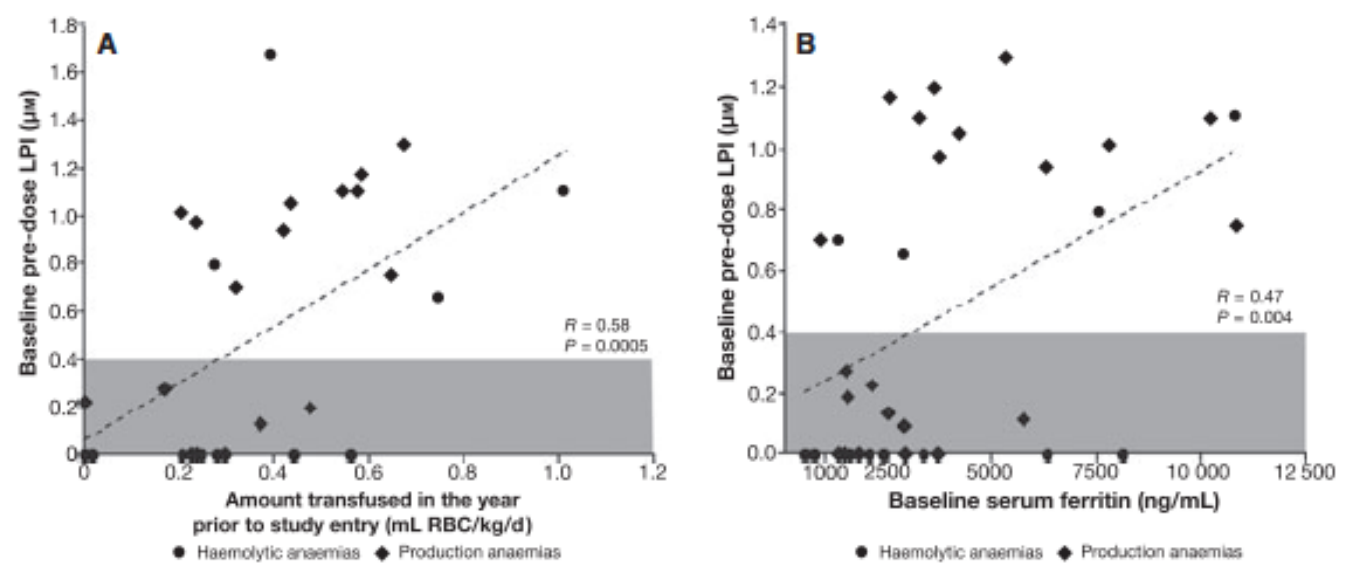

(A) The relationship between baseline pre-dose labile plasma iron (LPI) and transfusion rate in the year prior to study entry. There is a

significant correlation $(R=0.58, P=0.0005, n=32)$ between transfusion rate in the year prior to study entry and baseline pre-dose LPI in all

patients. Hemolytic anemias are shown in circles and production anemias in diamonds. The grey area denotes the healthy reference range.

(B) The relationship between baseline pre-dose LPI and baseline serum ferritin. There is a significant relationship $(R=0.47, P=0.004)$ between baseline ferritin and baseline pre-dose LPI for all patients. Hemolytic anemias are shown in circles and production anemias in diamonds. The grey area denotes the healthy reference range.

From Porter JB, Lin $\mathrm{KH}$, Beris $\mathrm{P}$, et al. Response of iron overload to deferasirox in rare transfusion-dependent anaemias: equivalent effects on serum ferritin and labile plasma iron for haemolytic or production anaemias. Eur J Haematol. 2011;87(4):338-348. Copyright (C) 2011 John Wiley \& Sons $\mathrm{A} / \mathrm{S}$ 
TABLES

Table 1. Conditions associated with transfusional Iron overload

\begin{tabular}{|c|c|c|c|}
\hline Condition & $\begin{array}{l}\text { Underlying mechanism } \\
\text { for iron overload }\end{array}$ & $\begin{array}{l}\text { Typical distribution } \\
\text { and mechanism }\end{array}$ & Consequences \\
\hline \multicolumn{4}{|l|}{ Inherited anemias } \\
\hline $\begin{array}{l}\text { Thalassemia Major } \\
\text { (TM) }\end{array}$ & $\begin{array}{l}\text { Blood transfusions for anemia }(+++) \\
\text { Increased iron absorption }(+)\end{array}$ & $\begin{array}{l}\text { High } \mathrm{NTBI}(++) \\
\text { Liver, heart, endocrine }\end{array}$ & $\begin{array}{l}\text { Cardiomyopathy } \\
\text { Endocrinopathy } \\
\text { Infection } \\
\text { Cirrhosis, hepatoma }\end{array}$ \\
\hline Sickle Cell Disease & $\begin{array}{l}\text { Intermittent transfusion }(++) \\
\text { Intravascular hemolysis with iron loss }(+\end{array}$ & $\begin{array}{l}\text { Liver predominantly } \\
\text { High erythron iron utilization } \\
\text { Low NTBI (+/-) }\end{array}$ & $\begin{array}{l}\text { Cirrhosis } \\
\text { (Extra-hepatic Iron) }\end{array}$ \\
\hline $\begin{array}{l}\text { Congenital } \\
\text { Dyserythropoietic } \\
\text { Anemia }\end{array}$ & $\begin{array}{l}\text { Ineffective erythropoiesis } \\
\text { Variable transfusion } \\
\sim 10 \% \text { of patients w CDA-I, } \\
\sim 5 \% \text { with CDA-II, } \\
<50 \% \text { with other CDA variants }\end{array}$ & $\mathrm{NTBI}^{121}(+)$ & $\begin{array}{l}\text { Not systematically } \\
\text { described }\end{array}$ \\
\hline $\begin{array}{l}\text { Sideroblastic } \\
\text { Anemia } \\
\text { Pyruvate Kinase } \\
\text { Deficiency (severe) }\end{array}$ & $\begin{array}{l}\text { Transfusion } \\
\text { Ineffective erythropoiesis } \\
\text { Transfusion dependence } \\
\text { Ineffective erythropoiesis } \\
\text { Extravascular hemolysis }\end{array}$ & $\begin{array}{l}\text { Hepatic, myocardial } \\
\text { High NTBI } \\
\text { Like NTD unless transfused }\end{array}$ & $\begin{array}{l}\text { Hepatic } \\
\text { Myocardial }()() \\
\text { Like NTDT } \\
\text { unless transfused }\end{array}$ \\
\hline $\begin{array}{l}\text { Diamond Blackfan } \\
\text { Anemia (DBA) }\end{array}$ & Transfusion dependence $(+++)$ & $\begin{array}{l}\text { Hepatic and extra-hepatic } \\
\text { Low erythron iron utilization } \\
\text { High NTBI }(+++)\end{array}$ & As with TM \\
\hline $\begin{array}{l}\text { Pure Red Cell } \\
\text { Aplasia }\end{array}$ & As above & As above & As above \\
\hline \multicolumn{4}{|l|}{ Acquired anemias } \\
\hline Aplastic Anemia & Blood transfusions for anemia & Liver, heart, endocrine & $\begin{array}{l}\text { Abnormal LFTs } \\
\text { Heart }^{122} \text { and } \\
\text { liver failure }^{123} \\
\text { LIC reduced by chelatic }\end{array}$ \\
\hline Fanconi anemia & Regular transfusion & Not well described & As above \\
\hline $\begin{array}{l}\text { Myelodysplasias } \\
\text { (MDS) }\end{array}$ & $\begin{array}{l}\text { Variable Blood transfusion late onset } \\
\text { Ineffective erythropoiesis }(++)\end{array}$ & $\begin{array}{l}\text { Hepatic } \\
\text { Extra-hepatic }>60-200 \text { units }\end{array}$ & $\begin{array}{l}\text { Hepatic }^{125} \\
\text { Cardiomyopathy } \\
\text { Infection }\end{array}$ \\
\hline Myelofibrosis & $\begin{array}{l}\text { High Blood transfusion late onset } \\
\text { Massive extra-vascular hemolysis }\end{array}$ & high LPI ?? & not described \\
\hline $\begin{array}{l}\text { Multiple } \\
\text { myeloablative } \\
\text { chemotherapies }\end{array}$ & Intermittent transfusion & myocardial iron $>100$ units & cardiomyopathy \\
\hline
\end{tabular}


Table 2. Abbreviations

\begin{tabular}{|c|c|c|c|}
\hline 4-HNE & 4-hydroxy-nonenal & LVEF & Left Ventricular Ejection Fraction \\
\hline AML & Acute Myeloid Leukemia & MAP & Mitogen-activated Protein Kinase \\
\hline BM & Bone Marrow & MDA & Malondialdehyde \\
\hline BMP & Bone Morphogenic Protein & MDS & Myelodysplastic Syndrome \\
\hline CDA & Congenital Dyserythropoietic Anemia & MIC & Myocardial Iron Content \\
\hline DBA & Diamond-Blackfan Anemia & MRI & Magnetic Resonance Imaging \\
\hline DcytB & Duodenal cytochrome B & MCSIO & Multi Center Study of Iron Overload \\
\hline DFO & Deferoxamine & NF-kB & $\begin{array}{l}\text { Nuclear Factor Kappa-light-chain-enhancer of } \\
\text { activated B cells }\end{array}$ \\
\hline DMT1 & Divalent Metal Transporter-1 & NTBI & Non-Transferrin-Bound Iron \\
\hline dw & dry weight & NTDT & Non-Transfusion-Dependent Thalassemia \\
\hline EPR & Electron Paramagnetic Resonance & PNH & Paroxysmal Nocturnal Hemoglobinuria \\
\hline ERK & Extracellular Signal-regulated Kinases & RES & Reticulo-Endothelial System \\
\hline GDF15 & Growth Differentiation Factor-15 & ROS & Reactive Oxygen Species \\
\hline Hbd & $\begin{array}{l}\text { Hemoglobin-deficit (mouse strain) } \\
\text { caused by Sec15l1 gene defect in the } \\
\text { vesicular trafficking pathway }\end{array}$ & SCD & Sickle Cell Disease \\
\hline HbS & Sickle Hemoglobin & SF & Serum Ferritin \\
\hline HFE & Hemochromatosis gene (High Iron $\mathrm{Fe}$ ) & SMAD & $\begin{array}{l}\text { Small Mothers Against Decapentaplegic } \\
\text { transcription factors pathway }\end{array}$ \\
\hline IE & Ineffective Erythropoiesis & STAT & Signal Transducer and Activator of Transcription \\
\hline IL-6 & Interleukin 6 & Tf & Transferrin \\
\hline ILR & Iron Load Rate & TfR1 & Transferrin Receptor-1 \\
\hline IRE & Iron Responsive Element & TGF $\beta-1$ & Transforming Growth Factor $\beta-1$ \\
\hline IRP & $\begin{array}{l}\text { Iron Regulatory Protein (iron responsive } \\
\text { element binding protein) }\end{array}$ & TIO & Transfusional Iron Overload \\
\hline LDH & Lactate Dehydrogenase & TM & Thalassemia Major \\
\hline LFTs & Liver Function Tests & UCLH & University College London Hospitals \\
\hline LIC & Liver Iron Content & UTR & Untranslated Region \\
\hline LIP & abile Intracellular Iron Pool & & \\
\hline
\end{tabular}

